The New Entrepreneurs 



\section{The New Entrepreneurs}

How Race, Class, and Gender

Shape American Enterprise

Zulema Valdez 
Stanford University Press

Stanford, California

(C) 2011 by the Board of Trustees of the Leland Stanford Junior University. All rights reserved.

No part of this book may be reproduced or transmitted in any form or by any means, electronic or mechanical, including photocopying and recording, or in any information storage or retrieval system without the prior written permission of Stanford University Press.

Printed in the United States of America on acid-free, archival-quality paper

Library of Congress Cataloging-in-Publication Data

Valdez, Zulema.

The new entrepreneurs : how race, class, and gender shape American enterprise / Zulema Valdez.

p. $\mathrm{cm}$.

Includes bibliographical references and index.

ISBN 978-0-8047-7320-1 (cloth : alk. paper)-ISBN 978-0-8047-7321-8 (pbk. : alk. paper)

1. Hispanic American businesspeople-Texas-Houston. 2. Hispanic American business enterprises-Texas-Houston. 3. Hispanic Americans-Texas-HoustonSocial conditions. 4. Hispanic Americans-Texas-Houston-Economic conditions. I. Title.

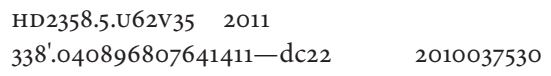

Typeset by Westchester Book Group in 10/14 Minion 
This book is dedicated with love to my parents, Joel G. Valdez and Margarita Zavala Valdez. 
